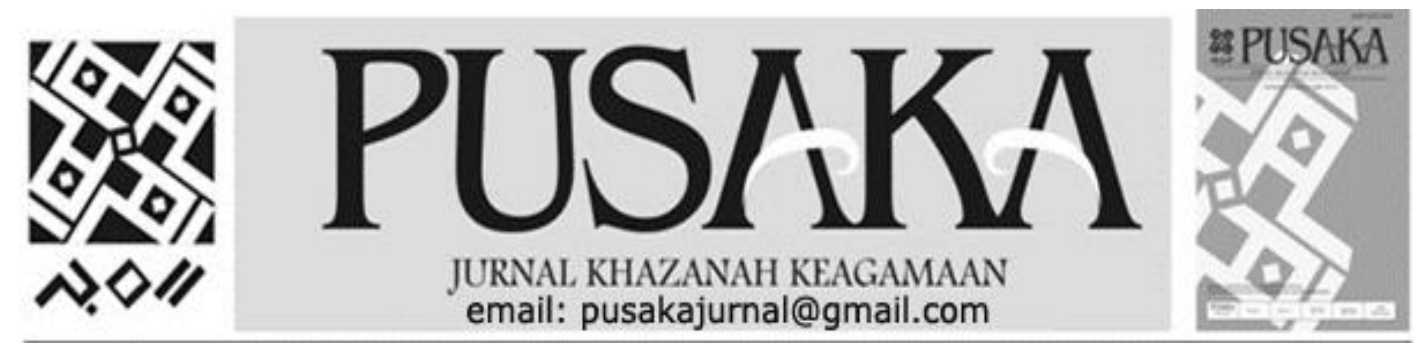

\title{
Pengelolaan Pendidikan Karakter Masyarakat Berbasis Budaya Makassar di SD Inpres Talakayya Kabupaten Bantaeng
}

\author{
Management of Character Building Based Makassar Cultural At SD Inpres \\ Talakayya Bantaeng District
}

\section{Mahmuddin}

Mahasiswa Program Pascasarjana Universitas Negeri Makassar

Email: mahmuddinuluere@gmail.com

\begin{tabular}{|c|c|}
\hline Info Artikel & Abstract \\
\hline $\begin{array}{c}\text { Diterima } \\
21 \\
\text { September } \\
2018 \\
\text { Revisi I } \\
2 \\
\text { Oktober } \\
2018\end{array}$ & $\begin{array}{l}\text { Penelitian ini bertujuan untuk mendeskripsikan pengelolaan pendidikan karakter masyarakat } \\
\text { berbasis budaya Makassar serta faktor pendukung dan penghambat di SD Inpres Talakayya } \\
\text { Desa Bonto Tangnga Kecamatan Uluere Kabupaten Bantaeng. Penelitian ini merupakan } \\
\text { penelitian kualitatif. Data dikumpulkan den gan tekn k k observasi, wawancara } \\
\text { dokumentasi, dan ditunjang dengan triangulasi untuk validitas data. Analisis data } \\
\text { menggunakan analisis interaktif. Hasil penelitian menunjukkan bahwa pengelolaan } \\
\text { pendidikan karakter m a s y a r a t berbasis budaya Makassar di SD Inpres Talakayya } \\
\text { dilaksanakan dengan menyesuaikan pada kurikulum dan materi pendidikan yang bermuatan } \\
\text { budaya Makassar serta mengintegrasikan materi yang mengandung unsur seni, bahasa dan } \\
\text { sistem sosial budaya Makassar. Materi yang disampaikan juga bermuatan nilai kejujuran, } \\
\text { kerendahan hati, kedisiplinan, kesopanan, kerja sama, kepedulian, dan tanggungawab. } \\
\text { Selain itu, disampaikan pula materi yang bersifat penanaman prinsip hormat, kerukunan } \\
\text { hidup, watak arif dan jujur, mawas diri, rendah hati, serta membentuk unggah-ungguh dan } \\
\text { tata krama yang baik sebagai wujud budi pekerti Makassar. Faktor pendukung dalam } \\
\text { pengelolaan pendidikan karakter berbasis budaya Makassar yaitu dinas pendidikan dan } \\
\text { pemerintah daerah, penyediaan fasilitas, komite dan orang tua peserta didik, managemen } \\
\text { sekolah, serta peserta didik berasal dari masyarakat Makassar. Faktor penghambat } \\
\text { pendidikan berbasis budaya Makassar yaitu belum adanya pedoman baku untuk pelaksanaan } \\
\text { program pendidikan yang bermuatan budaya Makassar, minat peserta didik terhadap budaya } \\
\text { Makassar, serta kekurangtahuan pendidik dalam mengoperasikan media belajar maupun } \\
\text { keadaan media belajar yang kurang mendukung untuk digunakan. } \\
\text { Kata Kunci: Pendidikan karakter, budaya Makassar, tari tradisional, kearifan lokal }\end{array}$ \\
\hline $\begin{array}{c}\text { Revisi II } \\
13 \\
\text { Oktober } \\
2018\end{array}$ & $\begin{array}{l}\text { This study aims to describe the management of the character education of the Makassar } \\
\text { culture-based community as well as supporting and inhibiting factors in SD Inpres } \\
\text { Talakayya, Bonto Tangnga Village, Uluere District, Bantaeng Regency. This research is a } \\
\text { qualitative research. Data is collected by observation, interview, documentation, and } \\
\text { supported by triangulation for data validity. Data analysis using interactive analysis. The } \\
\text { results showed that the management of the character education of the Makassar culture- } \\
\text { based community in SD Inpres Talakayya was carried out by adjusting to the curriculum } \\
\text { and educational material with a cultural content of Makassar and integrating material } \\
\text { containing elements of art, language and socio-cultural system of Makassar. The material } \\
\text { presented also contained values of honesty, humility, discipline, politeness, cooperation, } \\
\text { caring, and responsibility. In addition, the material that is also planted is the principle of } \\
\text { respect, harmony of life, character of wisdom and honesty, introspection, humility, and form } \\
\text { unggah-ungguh and good manners as a form of Makassar manners. Supporting factors in } \\
\text { the management of Makassar culture-based character education are education and local } \\
\text { government agencies, provision of facilities, committees and parents of students, school } \\
\text { management, and students from the Makassar community. The inhibiting factor of } \\
\text { Makassar culture-based education is the absence of standard guidelines for the } \\
\text { implementation of educational programs that contain Makassar culture, students' interest in } \\
\text { Makassar culture, as well as lack of knowledge of educators in operating the learning } \\
\text { media and the state of learning media that are less supportive to use. } \\
\text { Keywords: Character education, Makassar culture, traditional dance, local wisdom }\end{array}$ \\
\hline
\end{tabular}




\section{PENDAHULUAN}

Membicarakan karakter merupakan hal sangat penting dan mendasar. Orang-orang yang berkarakter kuat dan baik secara individual maupun sosial ialah mereka yang memiliki akhlaq, moral, dan budi pekerti yang baik. Mengingat begitu pentingnya karakter, maka institusi pendidikan memiliki tanggung Makassar untuk menanamkannya dalam diri peserta didiknya. Pendidikan karakter dimaknai sebagai suatu perilaku yang di dalam penyelenggaraan pendidikan harus berkarakter dan berpijak dari karakter dasar manusia dari nilai moral yang bersumber dari agama dan dengan sadar mau melaksanakan nilai-nilai tersebut, baik terhadap Tuhan Yang Maha Esa, diri sendiri, sesama, lingkungan, maupun kebangsaan sehingga menjadi insan kamil. Dalam pendidikan karakter di sekolah, semua komponen harus dilibatkan, termasuk komponenkomponen pendidikan itu sendiri, yaitu isi kurikulum, proses pembelajaran, penilaian, kualitas hubungan, pengelolaan mata pelajaran, sekolah, aktivitas atau kegiatan ekstrakurikuler, pemberdayaan sarana prasarana, pembiayaan, dan etos kerja seluruh warga dan lingkungan sekolah.

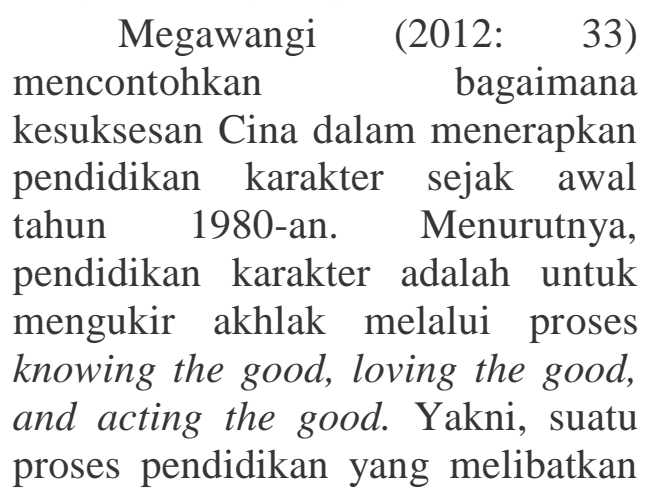

aspek kognitif, emosi, dan fisik, sehingga akhlak mulia bisa terukir menjadi habit of the mind, heart, and hands. "Belajar di masa kecil ibarat mengukir diatas batu, sedangkan belajar ketika sudah dewasa ibarat mengukir di atas air". Istilah tersbut sangat populer dan memiliki makna yang dalam. istilah tersebut juga mempunyai makna yang sesuai dengan konsep pendidikan anak usia dini yang sangat mementingkan stimulasi sejak dini agar anak dapat belajar banyak dan mengembangkan potensi dan minat yang dimiliki anak yang akan memberikan pengalaman dan kenangan yang begitu kuat terhadap anak, hal ini sangat berbeda ketika kita sudah dewasa apalagi kita menyinggung tentang karakter dan watak yang sudah menjadi kesatuan dalam kepribadian sehingga untuk merubahnya akan jauh lebih sulit. Sehingga penanaman karakter sejak dini menjadi kunci utama dalam membentuk karakter positif anak dan menjadi pondasi kepribadian yang akan menjadi orang yang memiliki karakter kuat.

Pendidikan karakter dapat diintegrasikan pada setiap materi yang disampaikan dalam metode pembelajaran yang ada di tingkat Sekolah Dasar yang meliputi sekurang- kurangnya 3 hal yaitu: Pertama afektif, yang tercermin dalam kualitas keimanan, ketakwaan, akhlak mulia termasuk budi pekerti luhur serta berkepribadiaan unggul, dan kompetensi estestis. Kedua kognitif, yang tercermin kepada kwalitas fikir, dan daya intelektualitas untuk menggali dan mengembangkan serta 
menguasai ilmu pengetahuan dan tekhnologi tentu saja yang berdasar kepada pendidikan nilai, norma dan akhlaq sebagai landasan pendidika karakter. Ketiga psikomotorik, yang tercermin kepada kemampuan mengembangkan ketrampilan teknis, kecakapan praktis, dan kompetensi kinestetis.

Pendidikan karakter di tingkat Sekolah Dasar juga sangat terkait dengan manajemen atau pengelolaan sekolah. Pengelolaan sekolah dimaksudkan dengan bagaimana pendidikan karakter direncanakan, dilaksanakan, dan dikendalikan dalam kegiatankegiatan disekolah yang meliputi; nilai-nilai yang perlu ditanamkan, muatan kurikulum, pendidikan dan tenaga pendidikan dan komponen terkait lainnya seperti hubungan sekolah dengan wali murid sebagai pendidik anak diluar jam sekolah dengan menggunakan perantara buku penghubung.

Dalam pelaksanaan praktik pendidikan yang ada di Indonesia baik dalam setara pendidikan dasar, menengah maupun tingkat atas, apabila dilihat dari standar nasional pendidikan yang menjadi acuan pengembangan kurikulum 2013, serta implementasi dan penilaian di sekolah, tujuan pembelajaran di tingkat Sekolah Dasar sebenarnya sudah dapat dicapai dengan baik melalui metode pembelajaran yang beraneka ragam dan berkembang sesuai dengan tingkat perkembangan anak. Termasuk pendidikan karakterpun sudah mulai dikenalkan dan dimasukkan dalam metode pembelajaran yang ada di tingkat Sekolah Dasar. Permasalahannya, pendidikan karakter di tingkat Sekolah Dasar masih dalam tingkatan pengenalan dan pembiasaan ketika jam pembelajaran di sekolah, dan belum pada tingkatan implementasi dan tindakan nyata dalam kehidupan sehari-hari baik di rumah maupun dalam aktivitas diluar jam pembelajaran di sekolah.

Guru di Sekolah Dasar Inpres Talakayya Kabupaten Bantaeng dalam mengajarkan pendidikan karakter budaya Makassar kepada siswanya, mereka tidak hanya memberikan konsep kepada para siswa tentang karakter apa dan mana yang dianggap sesuai oleh masyarakat, tetapi juga berusaha untuk menjalankannya. Bagi guru, Panutan tidak akan berhasil jika hanya diucapkan saja, tanpa dilaksanakan, dan ini sesuai dengan adagium yang muncul dengan istilah "Singkamma Loka A'buah Taipa" (ibarat pisang berbuah mangga, bicara mudah tetapi menjalankannya susah).

Sementara itu, terkait dengan peran guru dalam menerapkan pendidikan karakter berbasis budaya Makassar pada anak di Sekolah Dasar Talakayya Bantaeng yang merupakan program unggulan, tentunya akan disesuaikan dengan budaya Makassar, tentang Sipakalabbiri/tata krama yang dapat dimasukkan dengan nilai-nilai karakter yang ada. Dalam teori perkembangan, anak akan tumbuh dan berkembang dengan baik tidak saja cukup mengandalkan potensi yang dibawanya secara genetik akan tetapi juga sangat ditunjang oleh faktor lain yaitu lingkungannya sebagaimana dinyatakan oleh John Lock (1632-1704) melalui teori 
empirismenya yang beranggapan bahwa "manusia lahir dalam keadaan tabularasa, putih bersih bagaikan kertas yang belum ditulisi. Lingkunganlah yang membentuk seseorang menjadi manusia seperti dia pada waktu dewasa" (Irwanto, CS dalam Sofiah, 2012: 212).

Tujuan penelitian ini adalah:

1) Mendeskripsikan pengelolaan pendidikan karakter berbasis budaya Makassar di SD Inpres Talakayya. 2) Mendeskripsikan faktor pendukung dan penghambat pengelolaan pendidikan karakter berbasis budaya Makassar di SD Inpres Talakayya.

\section{METODE PENELITIAN}

Jenis penelitian ini adalah penelitian deskriptif. Penelitian diskriptif adalah penelitian yang dilakukan untuk mengetahui nilai variabel mandiri, baik satu variabel atau lebih (independen) tanpa membuat perbandingan, atau menghubungkan dengan variabel yang lain (Sugiyono, 2012: 115). Desain yang digunakan dalam penelitian ini adalah desain penelitian deskriptif kualitatif, yaitu penelitian yang berlandaskan pada filsafat postpositivisme, digunakan untuk meneliti pada kondisi objek yang alamiah, dimana peneliti adalah sebagai instrumen kunci, teknik pengumpulan data dilakukan secara triangulasi (gabungan), analisis data bersifat induktif/kualitatif dan hasil penelitian kualitatif lebih menekankan makna dari pada generalisasi (Sugiyono, 2010: 9). Deskripsi dalam penelitian ini mengenai pengelolaan pendidikan karakter berbasis budaya Makassar di SD Inpres Talakayya Kabupaten Bantaeng.

Pelaksanaan penelitian ini adalah SD Inpres Talakayya Kabupaten Bantaeng saat ini memiliki jumlah Kelompok Belajar sebanyak 6 Rombongan Belajar, Adapun jumlah tenaga pendidik sebanyak 7 orang, 1 kepala sekolah dan 8 orang tenaga honorer. Validitas data yang digunakan dalam penelitian ini adalah triangulasi sumber dan triangulasi teknik. Teknik analisa data yang digunakan dalam penelitian tersebut adalah model analisis interaktif (model saling terjalin). Dalam model analisis interaktif, tiga komponen yakni reduksi data, sajian data dan penarikan kesimpulan dilakukan berbentuk interaksi dengan proses pengumpulan data sebagai proses siklus.

\section{PEMBAHASAN}

Pengelolaan Pendidikan Karakter Berbasis Budaya Makassar di SD Inpres Talakayya Kabupaten Bantaeng

Penyelenggaraan pendidikan berbasis budaya Makassar merupakan salah satu cara untuk menyampaikan muatan budaya Makassar melalui pendidik anakanak. Melalui pendidikan ini dapat disampaikan berbagai unsur, nilai dan budi pekerti serta pengembangan minat dan bakat peserta didik dalam keterampilan seni budaya Makassar. Konsep pendidikan berbasis budaya Makassar ini mendukung dalam pembentukan karakter peserta didik melalui peningkatan kemampuan pengetahuan yang diiringi penanaman budi pekerti dan nilai- 
nilai budaya Makassar. Selain itu, pendidikan ini juga salah satu wujud pelestarian budaya Makassar melalui pengenalan sejak dini terhadap peserta didik.

SD Inpres Talakayya Kabupaten Bantaeng menunjukkan implementasi pendidikan berbasis budaya melalui berbagai komponen pendidikan. Pengertian pendidikan secara khusus menurut Dewantara (2011: 13) adalah salah satu usaha untuk memberian segala nilai-nilai kebatinan yang ada dalam hidup rakyat yang berbudaya kepada setiap generasi, tidak hanya berupa pemeliharaan akan tetapi juga dapat dimaksud memajukan serta mengembangkan kebudayaan menuju kearah keluhuran hidup manusia. Hal tersebut menununjukkan bahwa seharusnya pendidikan tidak hanya memelihara kebudayaan tetapi bahkan memajukan dan mengembangkan tanpa meninggalkan karakteristik budaya itu sendiri. Inilah yang coba direalisasikan oleh SD Inpres Talakayya dalam pendidikannya. Unsur-unsur budaya Makassar sebagai kearifan budaya lokal digunakan untuk memenuhi kebutuhan peserta didik sesuai kodrat alamnya selain dalam hal pengetahuan umum.

SD Inpres Talakayya ini melaksanakan sistem among sebagai sistem pendidikan. Sistem among merupakan pencerminan dari tut wuri handayani pada semboyan pendidikan Ki Hadjar Dewantara. Seperti pengertian sistem among pada pasal 12 Piagam dan Peraturan Besar Persatuan Taman Siswa (Fudyartanta, 1986: 12) yang dirumuskan sebagai suatu sistem pendidikan yang berjiwa kekeluargaan dan bersendikan dua dasar, yaitu: (1) Kodrat Alam, sebagai syarat untuk mencapai kemajuan dengan secepat-cepatnya dan sebaik-baiknya; dan (2) Kemerdekaan, sebagai syarat untuk menghidupkan dan menggerakkan kekuatan lahir batin peseta didik agar dapat memiliki pribadi yang kuat dan dapat berfikir serta bertindak merdeka. Sistem tersebut menurut berlakunya juga disebut sistem "Tutwuri Handayani".

Di sekolah ini pendidik menjalankan perannya sebagai pemimpin ketika menyampaikan pembelajaran, sebagai teman yang mampu memberikan motivasi dan memposisikan diri sebagai pengamat yang mendukung ketika peserta didik mengaplikasikan ilmu yang diperoleh. Hal ini senada dengan pernyataan Purwanto (2011: 63) mengungkapkan bahwa dalam sistem among setiap pamong atau pendidik sebagai seorang pemimpin dalam proses pendidikan diwajibkan bersikap 1) Ing Ngarsa Sung Tuladha yang artinya jika pendidik sedang berada di depan maka hendaknya memberikan contoh teladan yang baik terhadap peserta didiknya, 2) Ing Madya Mangun Karsa yang berarti jika pendidik sedang berada di tengah-tengah peserta didiknya maka hendaknya pendidik dapat mendorong kemauan atau kehendak peserta didik dan membangkitkan hasrat peserta didik untuk berinisiatif dan bertindak, dan 3) Tut Wuri yang berarti mengikuti dari belakang dan Handayani yang berarti mendorong, memotivasi atau membangkitkan semangat.

Sistem pendidikan sekolah ini 
merupakan sistem pendidikan yang berpusat pada peserta didik dimana seluruh usaha pendidikan bertujuan untuk perkembangan kemampuan peserta didik secara maksimal. Melalui penerapan sistem among dikembangkan pendidikan berbasis budaya Makassar ke berbagai hal yaitu: (1) Penerapan pada visi, misi dan tujuan sekolah; (2) Penyesuaian pada kurikulum dan materi pendidikan; (3) Pengajaran melalui program pendidikan; (4) Pemodelan dan pembiasaan dari pendidik; dan (5) Pengkondisian sarana dan lingkungan sekolah.

$\begin{array}{ccc}\text { SD } & \text { Inpres Talakayya } \\ \text { melakukan penyesuaian pada }\end{array}$
kurikulum dan materi pendidikan sehingga lebih kondusif dalam menyampaikan muatan budaya Makassar. Selain itu, sekolah ini juga memaksimalkan penyampaian materi yang bermuatan budaya Makassar. Materi budaya Makassar ini dapat berupa unsur-unsur, nilai maupun budi pekerti Makassar. Nilai dan budi pekerti Makassar tidak disampaikan melalui pelajaran melainkan terintegrasi dalam semua pelajaran. Hal ini seperti yang dikemukakan oleh Endraswara (2006: 5) bahwa berbagai nilai dan budi pekerti akan disisipkan secara integrated pada materi pelajaran lain. Jadi, budi pekerti bukanlah mata pelajaran yang berdiri sendiri karena budi pekerti adalah sikap dan perilaku afektif yang bersifat afekti. Sedangkan unsur-unsur seni, bahasa dan sosial dari budaya Makassar direalisasikan kedalam beberapa pelajaran dan ekstrakulikuler.

Unsur yang disampaikan melalui program didominasi oleh seni budaya Makassar. Peranan istimewa dari seni budaya ini bukan dimaksudkan untuk mendukung pendidikan atau pengajaran umum sehingga dihasilkan manusia yang tidak hanya terdidik nalar atau pengetahuannya saja tapi juga keluhuran dari keindahan serta kehalusan dari seni budaya itu sendiri.

Selain itu, unsur bahasa dan sistem sosial juga disampaikan melalui program pendidikan yang menyampaikan Bahasa Makassar serta Sipakalabbiri atau tata krama. Melalui program ini peserta didik bertambah pengetahuan dan pemahamannya terhadap budaya Makassar terutama bahasa Makassar serta sebagai salah satu bentuk pelestarian budaya. Bahasa memiliki peranan yang penting pada suatu budaya tidak terkecuali budaya Makassar. Identitas suatu budaya salah satunya terlihat dari bahasa yang digunakan. Dalam pelaksanaannya sekolah ini memang mendukung penggunaan bahasa daerah atau bahasa Makassar tapi juga terbuka dalam mempelajari bahasa lain seperti bahasa Indonesia dan bahasa Inggris untuk menambah pengetahuan dan wawasan peserta didik.

Nilai-nilai budaya Makassar yang disampaikan dan terlihat dalam penyelenggaraan pendidikan lebih pada nilai kejujuran, kerendahan hati, kedisiplinan, kesopanan, kerja sama, kepedulian, dan tanggung.

Nilai-nilai budaya Makassar tadi ditonjolkan melalui pemaknaan terhadap filosofi Makassar yang ada pada syair tembang, dongeng, gerakan tari, maupun berbagai kegiatan pada pembelajaran yang 
berkaitan. Nilai luhur budaya Makassar yang dimaksud tersebut identik dengan pendidikan karakter yang ditanamkan pada peserta didik melalui berbagai strategi.

\begin{tabular}{lrr}
\multicolumn{1}{c}{ Dalam } & \multicolumn{2}{c}{ penyelenggaraan } \\
pendidikan & berbasis & budaya \\
Makassar SD & Inpres & Talakayya \\
menanamkan & prinsip & hormat,
\end{tabular}
kerukunan hidup, watak arif dan jujur, mawas diri, rendah diri, serta membentuk unggah-ungguh dan tata krama yang baik. Prinsip-prinsip tadi merupakan prinsip yang dipegang oleh masyarakat budaya Makassar untuk membentuk budi pekerti dan akhlak mulia sebagai bentuk pendidikan moral masyarakat Makassar. Pada masyarakat Makassar prinsip hormat sangat dijunjung dan menjadi prinsip utama yang diajarkan pada anak- anaknya. Prinsip hormat yang dimaksudkan lebih pada menghormati lain terutama orang tua. Prinsip yang selanjutnya kerukunan hidup yang merujuk pada keselarasan sosial dari budaya saling menghargai. Watak arif dan jujur, mawas diri, serta rendah diri merupakan bentuk penanaman budi pekerti menuju keutamaan hidup bagi masyarakat Makassar. Sedangkan untuk unggah-ungguh dan tata krama merupakan suatu bentuk aturan yang harus diaplikasikan untuk mendidik kesopanan pada masyarakat Makassar (Endraswara, 2006: 23).

Sekolah ini mewujudkan muatan budaya Makassar pada pengajaran program intrakulikuler yaitu seni tari, seni suara daerah, dan batik. Sedangkan untuk ekstrakulikuler sekolah ini memiliki program ekstra kulikuler wajib bahasa Makassar, ekstra kulikuler pilihan karawitan dan dolanan anak. Melalui berbagai program ini ditingkatkan kemampuan peserta didik dalam pengetahuan dan keterampilan budaya Makassar. Dalam pelaksanaannya beberapa program- program pendidikan berbasis budaya Makassar sudah dapat menyampaikan materi budaya Makassar dengan baik dan menyampaikan maksud, nilai serta budi pekerti yang terkandung dalam materi tersebut. Namun masih ada beberapa program yang hanya berorientasi pada pengetahuan, keterampilan dan lomba saja walaupun sebenarnya program ini merupakan peluang untuk pendidikan karakter. Pada program dolanan anak dan karawitan sebenarnya bisa dipetik berbagai budi pekerti dan nilai-nilai kearifan budaya Makassar dari sejarah, tujuan dan fungsi dari berbagai materi yang disampaikan. Tapi sebagai pengenalan budaya Makassar sejak dini untuk menumbuhkan rasa cinta terhadap budaya bangsa sekolah ini sudah memaksimalkan sumberdaya yang ada melalui berbagai programprogram tersebut.

Dari hasil pelaksanaan program didapati bahwa peserta didik cukup tertarik dengan berbagai program yang menyampaikan budaya Makassar. Ketertarikan itu direalisasikan melalui keaktifan mereka dalam mengikuti program sehingga menghasilkan prestasi yang membanggakan terutama dalam bidang budaya Makassar seperti Tari-tariang, Kacapi, Sinrili Melalui program pendidikan 
berbasis budaya ini terlihat perebedaan karakteristik peserta didik sekolah ini dengan sekolah lain. Peserta didik sekolah ini lebih memiliki pengetahuan dan keterampilan budaya Makassar serta sopan santun dalam bergaul terutama dengan orang yang lebih tua.

Pelaksanaan pendidikan berbasis budaya Makassar juga dibiasakan melalui pemodelan dan pembiasaan dari pendidik dalam hal bersosialisasi di lingkungan sekolah berdasarkan Sipakalabbiri, tata krama dan nilai budaya Makassar. Pemodelan yang dilakukan oleh pendidik secara langsung antara lain dalam hal kerapihan berpakaian sopan santun dalam tingkah laku dan tutur kata. Selain itu pendidik juga memberikan contoh datang tepat waktu dan berjabat tangan saat bertemu dengan peserta didik maupun wali atau orang tua sebagai langkah awal pembiasaan. Seperti yang disampaikan oleh Endraswara (2006: 15), bahwa sebagai warisan budaya, nilai, sosialisasi budi pekerti jelas diperlukan figur dan contoh-contoh yang jelas dari generasi sebelumnya. Melalui tauladan dan media yang menarik, otomatis seseorang akan dapat menyerap konsep-konsep budi pekerti dan pada gilirannya dapat mengaplikasikan.

Selain itu pendidik juga melakukan pembiasaan kepada peserta didik yang mengarahkan untuk aplikasi nilai-nilai dan budi pekerti dari budaya Makassar. Kegiatan pembiasaan yang dilakukan antara lain:

Bersalaman sebelum masuk ruang kelas dan sebelum pulang peserta didik menjadi lebih disiplin dan teratur; (2) Menggunakan bahasa Makassar yang halus untuk berkomunikasi dengan pendidik maupun antar peserta didik terutama saat pelajaran bahasa Makassar; dan (3) Hal-hal kecil seperti ketika ingin meminta izin kebelakang. Pendidik juga membiasakan peserta didik untuk mengaplikasikan Sipakalabbiri dan tata krama selama pelajaran berlangsung maupun diluar kegiatan pembelajaran melalui arahan yang nyata dan jelas misalnya bersalaman dengan dengan pendidik saat datang dan pulang sekolah. Pembiasaan tata krama juga dilakukan di berbagai kesempatan melalui arahan langsung kepada peserta didik.

Selanjutnya, implementasi pendidikan berbasis budaya Makassar juga dilakukan melalui pengkondisian sarana prasarana dan lingkungan sekolah. Sarana yang dimaksimalkan untuk mendukung program pendidikan berbabasis budaya Makassar adalah LCD proyektor, tape recorder dan speaker. Sedangkan sarana pendukungnya meliputi ruang kelas dan halaman sekolah.

\section{Faktor Pendukung dan Penghambat Pendidikan Berbasis Budaya Makassar.}

Dalam pelaksanaan
pendidikan berbasis budaya
Makassar ditemukan berbagai hal
yang menjadi faktor mendukung
maupun menghambat. Hal yang
menjadi faktor pendukung yang di
miliki sekolah ini yang pertama
adalah dari latar belakang sekolah
yang sejak awal memang terkonsep
menyenggarakan pendidikan dengan


muatan pengetahuan yang didukung muatan budaya lokal.

Dukungan berasal dari komite dan orang tua peserta didik dalam memaksimalkan penyelenggaraan pendidikan berbasis budaya Makassar. Bentuk dukungan dari komite dan orang tua beragam dalam hal materiil dan non materiil. Ada orang tua yang masukkan peserta didik ke sanggar hingga ikut terjun langsung membantu peserta didik latihan bila akan mengikuti lomba. Managemen sekolah didukung dengan adanya kepala sekolah yang memiliki kemampuan dan pengalaman yang mumpuni sebagai kepala sekolah serta latar belakang budaya Makassar. Kompetensi sosial budaya dari pendidik dengan latar belakang budaya Makassar yang cukup juga mendukung penyelenggaraan pendidikan berbasis budaya Makassar di sekolah ini. Tingkat kemampuan pendidik di sekolah ini beragam tapi saling mendukung dalam pelaksanaan pendidikan berbasis budaya Makassar dengan berbagai pelatihan, saling sharing dan mencari referensi untuk meningkatkan kemampuan.

Hal pendukung dari peserta didik yaitu hampir $75 \%$ peserta didik berasal dari masyarakat Makassar. Karakteristik peserta didik secara umum adalah peserta didik yang aktif dengan rasa ingin tahu yang tinggi dengan sikap sopan dan santun memudahkan pendidik untuk menyampaikan materi budaya Makassar.

Selain faktor pendukung juga terdapat berbagai hal yang menghambat pelaksanaan pendidikan berbasis budaya
Makassar di SD Inpres Talakayya. Faktor yang menghambat pertama adalah belum ada pendidik yang benar-benar ahli dalam seni budaya batik untuk menjadi pengampu pelajaran batik. Selanjutnya belum semua pendidik berhasil memaksimalkan penyampaian materi budaya Makassar kepada peserta didik dikarenakan belum adanya pedoman baku untuk pelaksanaan beberapa program pendidikan budaya Makassar. Pendidik juga harus mengembangkan sendirisendiri sesuai kemampuan yang dimiliki.

Dari peserta didik pelaksanaan pembelajaran sering terhambat oleh minatnya terhadap budaya Makassar yang sering berubah-ubah. Kendala lain meskipun mayoritas peserta didik berasal dari masyarakat Makassar namun pengetahuan budaya Makassarnya masih sangat kurang. Selanjutnya, kekurangsiapan pendidik mengembangkan materi untuk peserta didik. Pendidik harus ekstra menyesuaikan materi agar bisa diterima dan dimaksimalkan oleh seluruh peserta didiknya.

$$
\text { Dalam hal fasilitas, }
$$
penggunaan media pembelajaran bahasa Makassar oleh pendidik kurang maksimal. Hal ini bisa disebabkan oleh kekurangtahuan pendidik mengoperasikan maupun keadaan media yang kurang mendukung untuk digunakan. Mayoritas program pendidikan berbais budaya Makassar di sekolah ini merupakan program yang mengajarkan seni budaya Makassar sehingga memerlukan peralatan pentas untuk memaksimalkan 
pelaksananya. Beberapa hambatan tersebut lebih karena sekolah ini merupakan sekolah swasta sehingga terkendala dana dalam penyediaan hal-hal pendukung pendidikan berbasis budaya Makassar.

Upaya yang dapat dilakukan untuk mengurangi faktor penghambatan pelaksanaan program pendidikan berbasis budaya Makassar adalah:

Menyelenggarakan pelatihan budaya Makassar untuk pendidik dengan bantuan dinas pendidikan maupun pihak dari luar sekolah; Membuat pedoman pelaksanaan beberapa program pendidikan budaya Makassar dengan bantuan pihak luar yang ahli sebagai acuan; (3) Peningkatan minat peserta didik melalui pengenalan dan pembelajaran yang menarik; dan (4) Berkoordinasi dengan dinas pendidikan untuk peningkatan fasilitas belajar budaya Makassar.

\section{PENUTUP}

Pengelolaan pendidikan karakter berbasis budaya Makassar di SD Inpres Talakayya dilaksanakan dengan menyesuaikan pada kurikulum dan materi pendidikan yang bermuatan budaya Makassar mengintegrasikan materi unsur seni, bahasa dan sistem sosial budaya Makassar, Menyampaikan materi bermuatan nilai kejujuran, kerendahan hati, kedisiplinan, kesopanan, kerja sama, kepedulian, dan tanggung Makassarb; dan menyampaikan materi yang menanamkan prinsip hormat, kerukunan hidup, watak arif dan jujur, mawas diri, rendah diri, serta membentuk unggah-ungguh dan tata krama yang baik sebagai wujud budi pekerti Makassar.

Faktor pendukung dan penghambat dari implementasi pendidikan berbasis budaya Makassar di SD Inpres Talakayya sangat beragam. Faktor pendukung yang dimiliki sekolah ini adalah: 1) peraturan dari dinas dan pemerintah daerah serta dukungan mengenai penyelenggaraan pendidikan berbasis budaya, 2) penyediaan fasilitas, dana dan tenaga pendidik pendukung dari dinas pendidikan, 3) komite dan orang tua peserta didik juga mendukung dalam hal materiil maupun non materiil, managemen sekolah dengan kepala sekolah yang berkompeten, 5) Mayoritas peserta didik berasal dari masyarakat Makassar. Sedangkan faktor penghambat implementasi pendidikan berbasis budaya Makassar di SD Inpres Talakayya adalah 1) belum adanya pedoman baku untuk pelaksanaan program pendidikan yang bermuatan budaya Makassar, 2) minat peserta didik terhadap budaya Makassar yang sering berubah-ubah, 3) kekurangtahuan pendidik mengoperasikan maupun keadaan media belajar yang kurang mendukung untuk digunakan.

\section{DAFTAR PUSTAKA}

Dewantara, K.H. 2011. Karya Ki Hadjar Dewantara Bagian Pertama: Pendidikan.

Endraswara, S. 2006. Metode, Teori, Teknik, Penelitian Kebudayaan Ideologi, Epsitemologi, dan Aplikasi. Sleman: Pustaka Widyatama. Megawangi, R. 2012, Pendidikan Karakter; Solusi Tepat Untuk Membangun Bangsa. Jakarta: 
Indonesia Heritage

Foundation.

Pawito. 2010. Penelitian

Komunikasi Kualitatif.

Yogyakarta: PT LkiS Pelangi.

Aksara. Purwanto. M.N. 2011. Ilmu

Pendidikan Teoritis dan

Praktik. Bandung: PT Remaja

Rosdakarya Samanim, M. dan

Hariyanto, 2012, Konsep dan

Model Pendidikan Karakter.

Bandung: PT Remaja Rosda

Karya.

Sofiah. 2012. Pendampingan

Orangtua dalam Upaya

Melindungi Anak dari Bahaya

Kecanduan Teknologi

Komunikasi. Surakarta: Jurnal

Komunikasi Massa Vol. 6 No.

2, Juli 2012.

Sugiyono. 2011. Metode Penelitian

Kuantitatif, Kualitatif dan $R$ \&

$D$. Bandung: Alfabeta

Sutopo, HB. 2010. Metodologi

Penelitian Kualitatif.

Surakarta. Sebelas Maret

Universitas Press.

Zubaedi. 2011. Desain Pendidikan

Karakter Konsepsi dan Aplikasinya dalam Lembaga

Pendidikan, Jakarta: Kencana.

Zulkifli. 2011. Psikologi

Perkembangan, Bagian

Perkembangan dalam Masa

Kanak-Kanak, Bandung:

Remaja Rosdakarya. 